\title{
XLVII. Contributions to the geology of Northumberland and Durham
}

\author{
N.J. Winch Esq. F.G.S. A.L.S.
}

To cite this article: N.J. Winch Esq. F.G.S. A.L.S. (1833) XLVII. Contributions to the geology of Northumberland and Durham , Philosophical Magazine Series 3, 3:16, 273-277, DOI: 10.1080/14786443308648175

To link to this article: http://dx.doi.org/10.1080/14786443308648175

册 Published online: 01 Jun 2009.

Submit your article to this journal $\pi$

Џ Article views: 2

Q View related articles $\sqsubset$ 


\section{[ 273 ]}

XLVII. Contributions to the Geology of Northumberland and Durham. By N. J. WInch, Esq. F.G.S. \& A.L.S.

[Concluded from p. 204.]

Section of the Strata of one of the Pits at Blenkinsop near Toadholes, sunk in the year 1826.

$$
\text { Isabella Pit. Fà. Yds. Ft. In. }
$$

GURFACE soil, clay, \&c.

$\begin{array}{llllllllll}\text { Plate or shale } & \ldots & \ldots & \ldots & \ldots & \ldots & 0 & 1 & 2 & 6\end{array}$

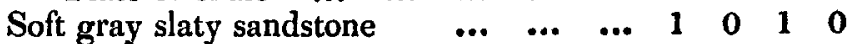

$\begin{array}{llllllllllll}\text { Plate } . . . & \ldots & \ldots & \ldots & \ldots & \ldots & \ldots & \ldots & 5 & 0 & 2 & 3\end{array}$

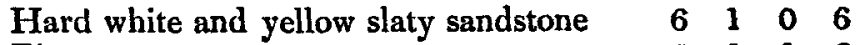

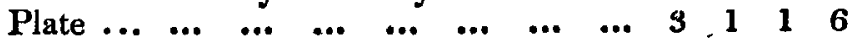

$\begin{array}{llllllllllll}\text { Limestone } & \ldots & \ldots & \ldots & \ldots & \ldots & \ldots & \ldots & 4 & 0 & 0 & 0\end{array}$

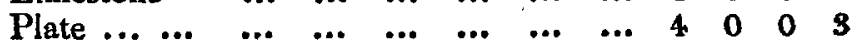

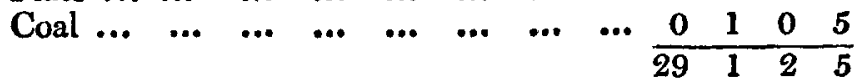

The pit called the Deep Pit, at Blenkinsop, was 56 fathoms; the upper part all clay, the lower strata corresponding with the above section.

Dip of the coal seam 1 yard in 9 yards.

Regular dip to 10 o'clock A.M.

No whin dykes; there are up and down carts. An out-burst of the coal seam at Little Angerton, in the township of Blenkinsop, 4 feet 6 inches in height. The seam varies from 4 feet 5 inches to 4 feet 8 inches in thickness. The colliery is wrought at present (1830) by a drift or tram-way. Only one workable seam. There is a small seam of crow coal 10 inches thick, but not workable.

I now give a statement of the sinking of another pit at the same colliery (not now at work), called the John Pit.

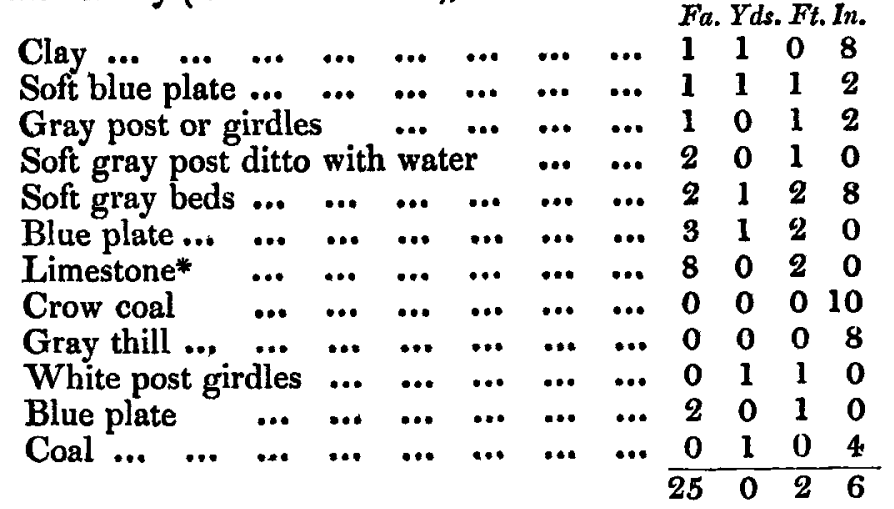

- A large kibbe or tub of fine-lead ore was found in this stratum when sinking the pit.

Third Series. Vol. 3. No. 16. Oct. 1833. 
The average of tonnage per day of the present working pit is $28 \frac{1}{4}$ tons. The annual working in the year 1829 was 2525 score loads, each load containing $4 \frac{1}{2}$ imperial bushels.

Seams of coal, inferior in thickness to those belonging to the Newcastle coal formation, and interstratified with the encrinal limestone, as well as with sandstone and shale, are spread over most parts of Northumberland; but owing to these landsale collieries being generally inconsiderable in point of depth and extent of workings, the continuity of the beds of coal has never been accurately ascertained. Sections of coal mines in this formation are to be found in the fourth volume of the first series of the Geological Transactions, p. 60, where an account of Shilbottle Colliery, which supplies Alnwick with fuel, is given: and in the Transactions of the Natural History Society of Newcastle, in vol. i. pp. 126, 127, 128,129 , sections of the more important mines in the vicinity of Berwick-upon-Tweed, are inserted. The section above is of the colliery close to the old castle of Blenkinsop, 33 miles west of Newcastle, and close to the borders of Cumberland: The viewer at this place considered the position of the coal to be below the four-fathom limestone, and above the great limestone of the Alston Moor miring field, and that the bed of coal was the same as that worked in the more extensive mines on Tynedale Fell. From these collieries Carlisle derives its coal. At Angerton, close to Blenkinsop, a very deep quarry is worked in the encrinal limestone before mentioned (see the section below); but I would here remark, that it is next to impossible to trace and identify the various strata of limestones and sandstones to any great distance from the places where they are well known on Alston Moor by the lead miners, for as these beds range towards the north and north-east, they divide and admit others between them; and I have every reason to think that this is even the case with that well-defined rock known by the name of the millstone grit.

Angerton Limestone Quarry, used for Lime, adjoining the present Working Pit (Height thereof) below the Coal.

\begin{tabular}{|c|c|c|c|c|c|}
\hline *First bad post or & top ston & & & $\cdots$ & 1 \\
\hline * Second ditto & $\ldots \quad \ldots$ & $\cdots$ & ... & $\ldots$ & 1 \\
\hline *Third ditto & $\ldots \quad \ldots$ & ... & ... & $\ldots$ & 1 \\
\hline First or good top & stone & $\ldots$ & ... & $\ldots$ & 3 \\
\hline *Damp bed ... & $\ldots \quad \ldots$ & $\cdots$ & ... & $\cdots$ & 0 \\
\hline Second top stone & $\cdots$ & ... & $\cdots$ & $\cdots$ & 3 \\
\hline
\end{tabular}




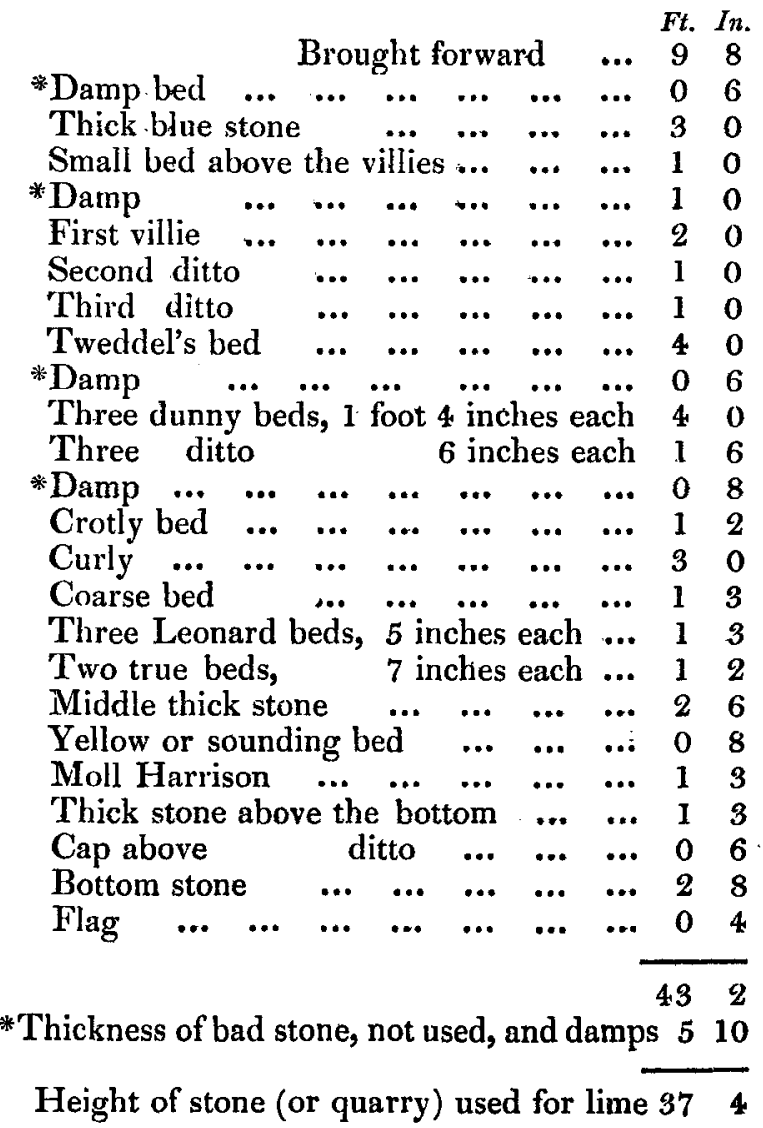

To the eastward of Blenkinsop, coal is worked at Haltwhistle, Milkbridge, Barkham, Haydon Bridge, Fourstones, opposite Warmley and Acomb or Fallowfield. These places are all in the limestone country, and the coal is thought to be the Blenkinsop seam, though reduced at Milkbridge to nineteen inches in thickness, and at Barkham, at which place the shaft is thirty fathoms and a half deep, from twenty to twenty-five inches. At Hayton Bridge the seam is about twenty inches thick, but at Fourstones it is as thick as at Blenkinsop. The following rough account of the strata sunk through at Acomb was obtained on the spot from an intelligent workman. 


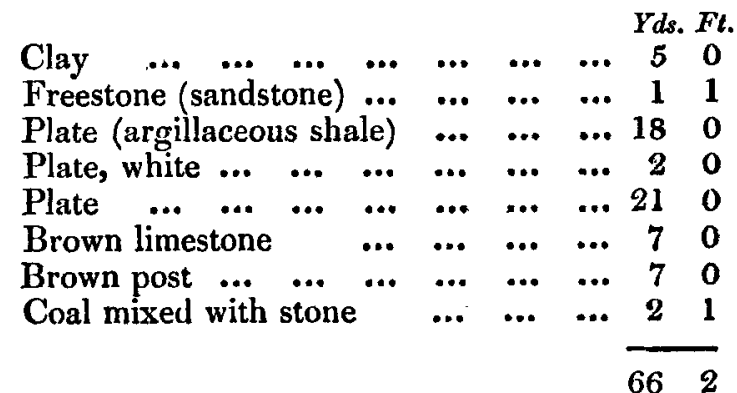

This may convey some general idea of the rocky beds passed through, but evidently is not to be relied upon like the other sections, which were procured from gentlemen employed in the higher departments of mining.

At Guilsland in the Vale of Irthing, three miles to the west of Blenkinsop, the strata consist of limestone, sandstone, coal, and shale; the latter peculiarly rich in nodules and thin subordinate strata of clay ironstone. One peculiar bed of blue limestone, about half a mile below the Spa, is intimately blended with minute fragments of coal. A seam of coal, two feet thick, crops out in the cliffs on the Wardrew side of the river: it has a good roof of sandstone, and is worked at the surface. by the farmers on the estate. Near Baron House, a mile and a half south-west of Wardrew, a seam of coal, three feet eight inches thick, crops out: from its situation, and the inclination of the strata in which it is imbedded, it must be lower in the series than the Blenkinsop seam. The course of the Irthing from Narworth to Guilsland is in the limestone formation; but at Leonard coast the new red sandstone of Cumberland makes its appearance. The limestone has been quarried on the banks of the river a little to the east of the bridge, and the red sendstone not far above it. The Abbey is chiefly built of this material, which, like the same description of stone at Melrose, seems, from its durability, well adapted to the purpose. Immense blocks of fine-grained gray granite are in this neighbourhood scattered over the face of the country, both on the encrinal limestone and on the new red sandstone. To return to the vicinity of Glenwhelt : a mass or irregular bed here crosses the rivulet, and is probably connected on the one hand with the well-known Walltown crags to the eastward, and on the other with the basalt quarried on the top of Windy-law Hill, close to the Carlisle turnpike road, to the westward. In the quarry the basalt assumes a rude columnar structure, and beautiful crystals of purple amethystine quartz are occasionally found in its interstices. In the vicinity of 
Mr. T. S. Davies on the Problem of Shortest Twilight. 277

Thirlwall Castle a bed of encrinal limestone reposes on the basalt, and, as is usually the case when in contact with that rock, has become crystalline in texture, and phosphorescent if laid on red-hot iron: its colour is also changed from dark blue to yellowish white.

Newcastle-upon-Tyne, Dec. 18, 1832.

XLVIII. On Bernoulli's Solution of the Problem of Shortest Trwilight. ByT.S. Davies, Esq.F.R.S. L.\& E., F.R.A.S.,\&c.

[Concluded from p. 185.]

BEFORE we proceed, however, to these supplementary theorems, we may make one or two other remarks upon the result just obtained.

By the theory of equations, if $\rho^{\prime}$ and $\rho^{\prime \prime}$ denote the values of $\rho$ in the last equation, $\rho^{\prime}$ referring to the minimum, and $\rho^{\prime \prime}$ to the maximum cases, we have

$$
\cos p^{\prime} \cos p^{\prime \prime}=\cos ^{2} \lambda
$$

which is independent of the almacantars between which the star moves. Also taking the difference,

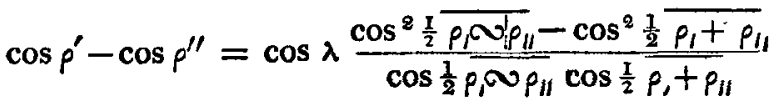

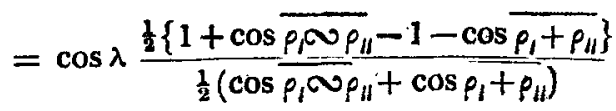

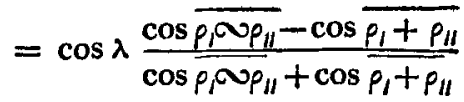

$$
\begin{aligned}
& =\cos \lambda \tan \rho_{,} \tan \rho_{1}
\end{aligned}
$$

which, when $\rho_{l}$ and $\rho_{l}$ (the zenith distances of the almacantars) are taken the complements of each other, the difference of the cosines of the polar distances of the sun for the maximum and minimum time is constant.

Again, from the same equation (9), we have

$$
\cos \rho^{\prime}+\cos p^{\prime \prime}=2 \cos \lambda \frac{1+\cos p_{1} \cos \rho_{\|}}{\cos \rho_{1}+\cos p_{\|}}
$$

and by division, we have

$$
\frac{\cos \rho^{\prime}}{\cos \rho^{\prime \prime}}=\frac{\cos ^{2} \frac{r}{2} \overline{\rho_{1} \sim \rho_{p_{11}}}}{\cos ^{2} \frac{1}{2} \overline{\rho_{1}+\rho_{i \prime}}}
$$

The question actually resolved is, - what declination of the 